ZOOLOGIA 29 (5): 439-450, October, 2012

doi: $10.1590 /$ S1984-46702012000500007

\title{
Four new species and two new records of Odostomiinae (Gastropoda: Pyramidellidae) from Brazil
}

\author{
Alexandre Dias Pimenta
}

Departamento de Invertebrados, Museu Nacional, Universidade Federal do Rio de Janeiro. Quinta da Boa Vista, São Cristóvão, 20940-040 Rio de Janeiro, RJ, Brazil. E-mail: alexpim@mn.ufrj.br

\begin{abstract}
Four new species of the pyramidellid Odostomiinae from Brazil are described: Chrysallida conifera sp. nov., characterized by a small and regularly conical shell with prominent nodules; Parthenina biumbilicata sp. nov., characterized by a deep and wide umbilicus and a regularly increasing aperture diameter at the protoconch, which bears a small circular umbilicus; Eulimastoma franklini sp. nov., which is very similar to Eulimastoma dydima (Verrill \& Bush, 1900) but has a prominent helicoid protoconch; Eulimastoma exiguum sp. nov., similar to Eulimastoma weberi (Morrison, 1965) but without spiral ridges. Fargoa diantophila (Wells \& Wells, 1961) and Chrysallida nioba (Dall \& Bartsch, 1911) are reported from the southwestern Atlantic for the first time.
\end{abstract}

KEY WORDS. Chrysallida; Eulimastoma; Fargoa; Parthenina; West Atlantic.

Pyramidellidae Gray, 1840 (superorder Heterobranchia) comprises a large group of marine microgastropod, ectoparasitic on other invertebrates. The family is distributed worldwide, from coastlines to the deep sea, and is one of the largest mollusk families, with over 6,000 named species (Peñas \& RoLÁn 1998) and more than 300 generic and subgeneric taxa (SCHANDER et al. 1999, 2003).

Despite these numbers, until the 1990s only 35 species were recorded from Brazil (Rios 1994) and taxonomic revisions in the past ten years (Pimenta et al. 2000, 2008, 2009, 2011 Pimenta \& Absalão, 2001a,b, 2002, 2004a,b; AbsalÃo et al. 2003) have revealed around 30 new species, in addition to several new records of species originally described from northern localities in the western Atlantic, mainly the Caribbean region, totaling about 95 species of Pyramidellidae in more than 20 genera. Some of these species were listed and poorly characterized and illustrated by Rios (2009).

The species of Odostominae, in particular, were revised in a series of papers (Pimenta \& ABSAlão 2004b, Pimenta et al. 2008, 2009), on Eulimastoma Bartsch, 1916, Egila Dall \& Bartsch, 1904, Ividia Dall \& Bartsch, 1904, Folinella Dall \& Bartsch, 1904, Oscilla A. Adams, 1861, Pseudoscilla Boettger, 1901, Boonea Robertson, 1978, Chrysallida Carpenter, 1856, Parthenina Bucquos, Dautzenberg \& Dollfus, 1883, Ivara Dall \& Bartsch, 1903, Fargoa Bartsch, 1955, Mumiola A. Adams, 1863, Odostomella Bucquos, Dautzenberg \& Dollfus, 1883, and Trabecula Monterosato, 1884.

Recent collection-based studies, as well as recent collections, led to the discovery of other species occurring in Brazil, belonging to some of the above-mentioned genera, including four new taxa, which are the scope of this paper.

\section{MATERIAL AND METHODS}

The taxonomic identifications were based on conchological comparisons with type material and/or original descriptions and illustrations. Each species was illustrated using scanning electron microscope (SEM) images. The abbreviation " $\mathrm{m}$ " refers to the depth (in meters) of the collecting locality.

The terminology used for protoconchs follows AARTSEN (1981, 1987), modified by Linden \& Eikenboom (1992) and SCHANDER (1994).

Most of the material examined was obtained from oceanographic expeditions off southeast Brazilian coast; names of these expeditions, dates and collectors are summarized below: (MD 55 Cruise) this expedition was carried out by Research Vessel "Marion Dufresne" in 1987, and samples were dredged from southeastern Brazil (TAVARES 1999). All lots, from MD55, were collected by Philippe Bouchet, José Leal, and Bernard Métivier. For more details, see TAVAREs (1999); (REVIZEE) "Programa de Avaliação do Potencial Sustentável de Recursos Vivos da Zona Econômica Exclusiva" (Program of Evaluation of the Sustainable Potential of Living Resources in the Economic Exclusive Zone), of the Ministério do Meio Ambiente, Brazilian Government; collectors: REVIZEE Central sta C1: Oceanographic Ship "Antares"; REVIZEE Central C5: supply boat N/ RB "Astro Garoupa"; REVIZEE Sul: Oceanographic Vessel "Professor W. Besnard"; (PADCT) "Programa de Apoio ao Desenvolvimento Científico e Tecnológico", carried out by Instituto Oceanográfico da Universidade de São Paulo (IOUSP), between November, 1997 and January, 1998; collector: Oceanographic Vessel "Professor W. Besnard"; (RAP Ilha Grande) Marine Rapid Assessment Protocol at Baía da Ilha Grande, Rio de 
Janeiro, carried out by Universidade do Estado do Rio de Janeiro; (HAB) Projeto Habitats - "Heterogeneidade Ambiental da Bacia de Campos" (Habitats Project - Campos Basin Environmental Heterogeneity), carried out by CENPES/PETROBRAS. Collector: Research Vessel "Miss Emma McCall".

Other abbreviations used through the text: IBUFRJ Instituto de Biologia, Universidade Federal do Rio de Janeiro, Rio de Janeiro; MNHN - Muséum National d'Histoire Naturelle, Paris; MNRJ - Museu Nacional/Universidade Federal do Rio de Janeiro, Rio de Janeiro; MORG - Museu Oceanográfico “Eliézer de Carvalho Rios", Fundação Oceanográfica do Rio Grande, Rio Grande; MZSP - Museu de Zoologia da Universidade de São Paulo, São Paulo; UERJ - Universidade do Estado do Rio de Janeiro; USNM - National Museum of Natural History, Washington, DC; ZMA - Zoölogisch Museum Amsterdam, Amsterdam.

\section{TAXONOMY}

\section{Pyramidellidae Gray, 1840 Odostomiinae Pelseneer, 1928}

Remarks. Pimenta et al. (2009) provided a brief review of the use of the name Odostomiinae and of some genera included in this subfamily. Taxonomists working on Pyramidellidae (e.g., Pimenta et al. 2009, Lygre et al. 2011) generally agree that the classification of the family at the generic level requires an extensive revision based on anatomical, developmental and molecular studies, and that shell characters alone do not provide enough evidence to clearly recognize the definitions and limits among the more than 300 generic names. For those reasons, the generic classification used here should be considered provisional, awaiting revision of the taxa. Some genera, such as Eulimastoma and Chrysallida are used in lato sensu, and most generic allocations follow previous authors and/or are based on conchological similarities.

\section{Fargoa Bartsch, 1955}

Fargoa Bartsch, 1955: 80. Type species by original designation: Fargoa calesi Bartsch, 1955, Pliocene, St. Petersburg, Florida.

\section{Fargoa diantophila (Wells \& Wells, 1961)}

\section{Figs 1-6}

Odostoma (Chrysallida) dianthophila Wells \& Wells, 1961: p. 152, figs 1-3.

Odostoma dianthophila: Abbott, 1974: 293, fig. 3489.

Fargoa dianthophila: Lyons, 1989: 29, pl. XII, fig. 8; Odé \& Speers, 1972: 10; Robertson, 1978: 373, fig. 6; 1996: 17, figs 16-18; Odé, 1993: 29; Lee, 2009: 141, fig. 682; Tunnell Jr et al., 2010: 265.

Type material. Holotype USNM 613499 (not examined). Type locality. Beaufort, North Carolina, USA.

Material examined. BraziL, Rio de Janeiro: Ponta Grande, baía da Ilha Grande (RAP Ilha Grande sta 17, 230.544"S, $\left.44^{\circ} 28.464^{\prime \prime} \mathrm{W}, 8.5 \mathrm{~m}\right), 10$ shells, 30/x/2003, UERJ 6224; Ponta Grande, baía da Ilha Grande (RAP Ilha Grande sta 17, $23^{\circ} 0.544^{\prime \prime} \mathrm{S}, 44^{\circ} 28.464^{\prime \prime} \mathrm{W}, 8.5 \mathrm{~m}$ ), 2 shells, 30/x/2003, MNRJ 17257.

Geographic distribution. USA: Massachusetts, North Carolina, Florida, Texas (Rosenberg 2009); Brazil: shallow waters off Rio de Janeiro state, southeast of Brazil (this study).

Remarks. Pimenta et al. (2009) recognized only one species of Fargoa occurring on the Brazilian coast: Fargoa bushiana (Bartsch, 1909). After study of the malacological collection at the UERJ, Fargoa dianthophila (Figs 1-6), originally described from the east coast of the United States, was recognized as occurring on the Brazilian coast. Fargoa bushiana and F. dianthophila have very similar geographical distributions in the northwestern Atlantic, from Massachusetts to the Texas coast. Fargoa buijsei de Jong \& Coomans, 1988, from the West Indies, is a synonym of $F$. bushiana, according to PIMENTA et al. (2009). In Brazil, while $F$. bushiana is widespread, from the northeast to southeast coasts $\left(\sim 2^{\circ} \mathrm{S}\right.$ to $\left.\sim 28^{\circ} \mathrm{S}\right)$, the known distribution of F. dianthophila was restricted, up to now, to the records presented here, from shallow waters in Ilha Grande Bay. The material studied here is very similar in dimensions, shape and sculpture to the original illustrations by WeLL \& WeLls (1961) and subsequent ones by LEE (2009) and TUNNELL JR et al. (2010). It has a minute, pupoid-shaped shell, a very immersed protoconch (Figs 3 and 4), identical sculpture (Figs 1-2 and 6), and fold at the columella (Fig. 6).

\section{Chrysallida Carpenter, 1856}

Chrysallida Carpenter, 1856: 170. Type species by original designation: Chemnitzia communis C.B. Adams, 1852. Recent, Mexico.

\section{Chrysallida nioba (Dall \& Bartsch, 1911) Figs 7-12}

Odostomia (Chrysallida) nioba Dall \& Bartsch, 1911: 286.

Chrysallida nioba: de Jong \& Commans, 1988: 122, pl. 6, fig. 543; Redfern, 2001: 143, pl. 64, fig. 592A, B; Lee, 2009: 138, fig. 671.

Type material. 6 syntypes USNM 223284 (examined through photographs).

Type locality. Bermuda.

Material examined. West Indies: Aruba, 15 shells, F. Veberne leg., ZMA; Curaçao, 4 shells, de Jong leg., ZMA; BrazIL: Rio de Janeiro: (HAB 16 sta F5, 22 $2^{\circ} 17^{\prime} 20.854^{\prime \prime}$, $40^{\circ} 6^{\prime} 42.755^{\prime \prime} \mathrm{W}$, 140 m), 1 shell, 05/vii/2009, MNRJ 16289; (REVIZEE Central sta C1-D3, 22 $\left.52^{\prime} \mathrm{S}, 41^{\circ} 09^{\prime} \mathrm{W}, 80 \mathrm{~m}\right), 22$ shells, 23/ii/1996, IBUFRJ 11333; (REVIZEE Central sta C1-D3, 22 $2^{\circ} 52^{\prime} \mathrm{S}, 41^{\circ} 09^{\prime} \mathrm{W}$, $80 \mathrm{~m}), 4$ shells, 23/ii/1996, MNRJ 17164.

Geographic distribution. USA: Florida, Louisiana; ABC Islands; Bermuda (Rosenberg 2009); Brazil: 80 to $140 \mathrm{~m}$ deep off Rio de Janeiro southeast of Brazil (this study). 


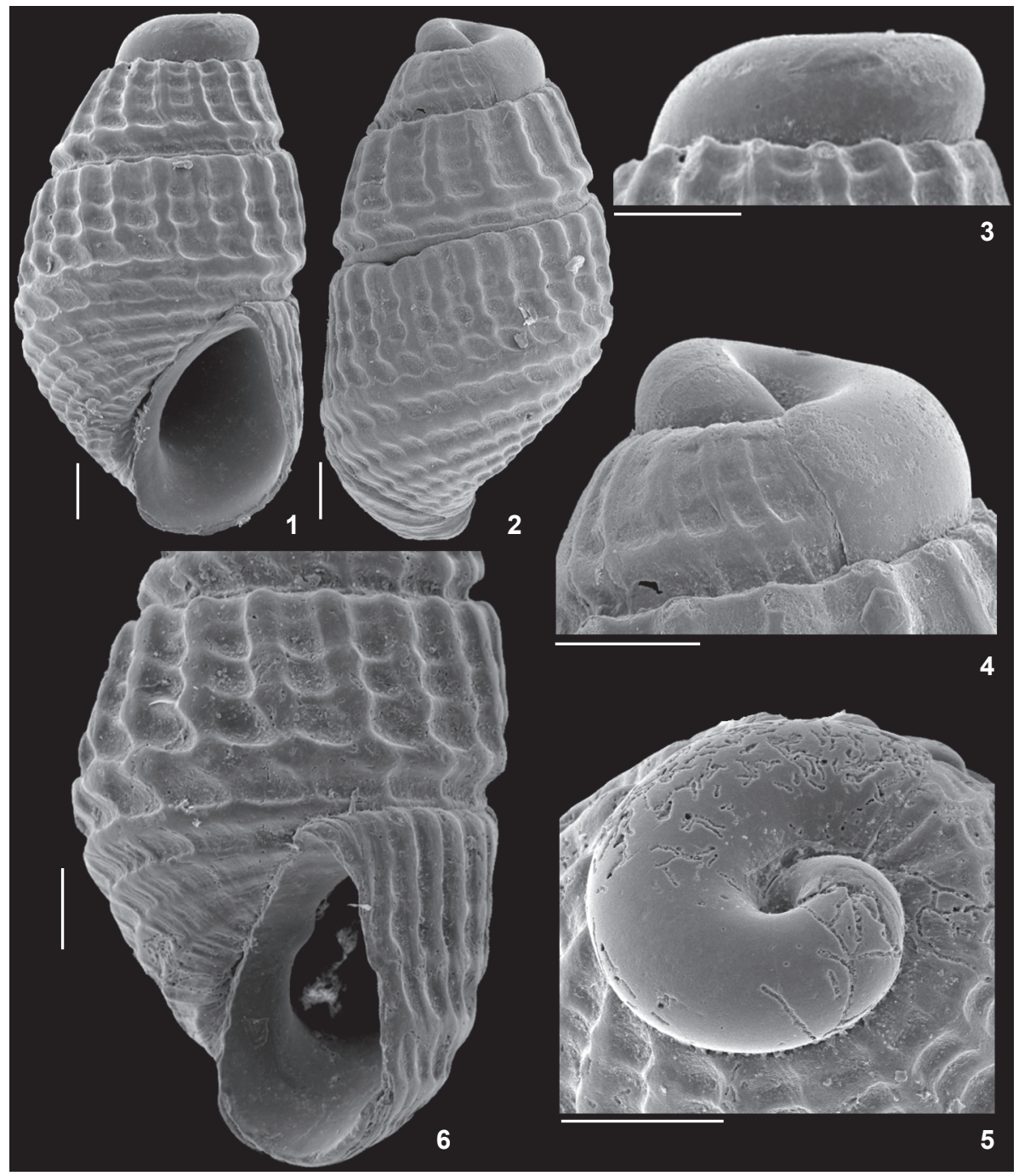

Figures 1-6. Fargoa dianthophila, UERJ 6224: (1-2) whole shell, length: 0,9 mm; (3-5) protoconch; (6) last whorl. Scale bars: $100 \mu \mathrm{m}$.

Remarks. Chrysallida nioba (Figs 7-12) was not illustrated with the original description. The type series contains six syntypes, one of which is illustrated in Figure 12. The subsequent records of this species from different localities in the Caribbean and the United States east coast are somewhat unclear. Although the drawing provided by DE Jong \& CoOMANs (1988) of shells from the West Indies does not allow recognition of the characteristics of the shell, examination of the ZMA collection confirms its occurrence at Aruba.

LEE (2009) presented a photograph of a shell very similar shape that to that of $C$. nioba noted a possible synonymy between C. nioba, Boonea seminuda (C.B. Adams, 1839) and Odostomia toyatani Henderson \& Bartsch, 1914. Actually, B. seminuda and Odostomia (Chrysallida) toyatani were synonymized by RoberTson (1978), but C. nioba must be considered a distinct species since it has a distinct protoconch, with immersed nucleus (Figs 9-11), while in the protoconch of $B$. seminuda the nucleus is visible; also, the shell shape and sculpture are different, more elongated and without smooth spiral cords above the suture as occurs in B. seminuda.

\section{Chrysallida conifera sp. nov.}

Figs 13-18

Type material. Holotype MNRJ 16300. Paratypes (one shell in each lot). MNRJ 16301 continental shelf of Bacia de

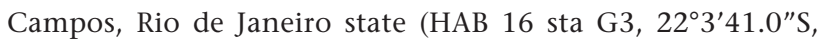
$\left.40^{\circ} 10^{\prime} 5.38^{\prime \prime} \mathrm{W}, 75 \mathrm{~m}\right), 06 / \mathrm{vii} / 2009$; IBUFRJ 19203, continental shelf of Bacia de Campos, Rio de Janeiro state (HAB 16 sta G3, 22 3'41.0"S, 40¹0'5.38”W, 75 m), 06/vii/2009; MNRJ 16302 type locality; MNRJ 16303, continental shelf of Bacia de Cam- 


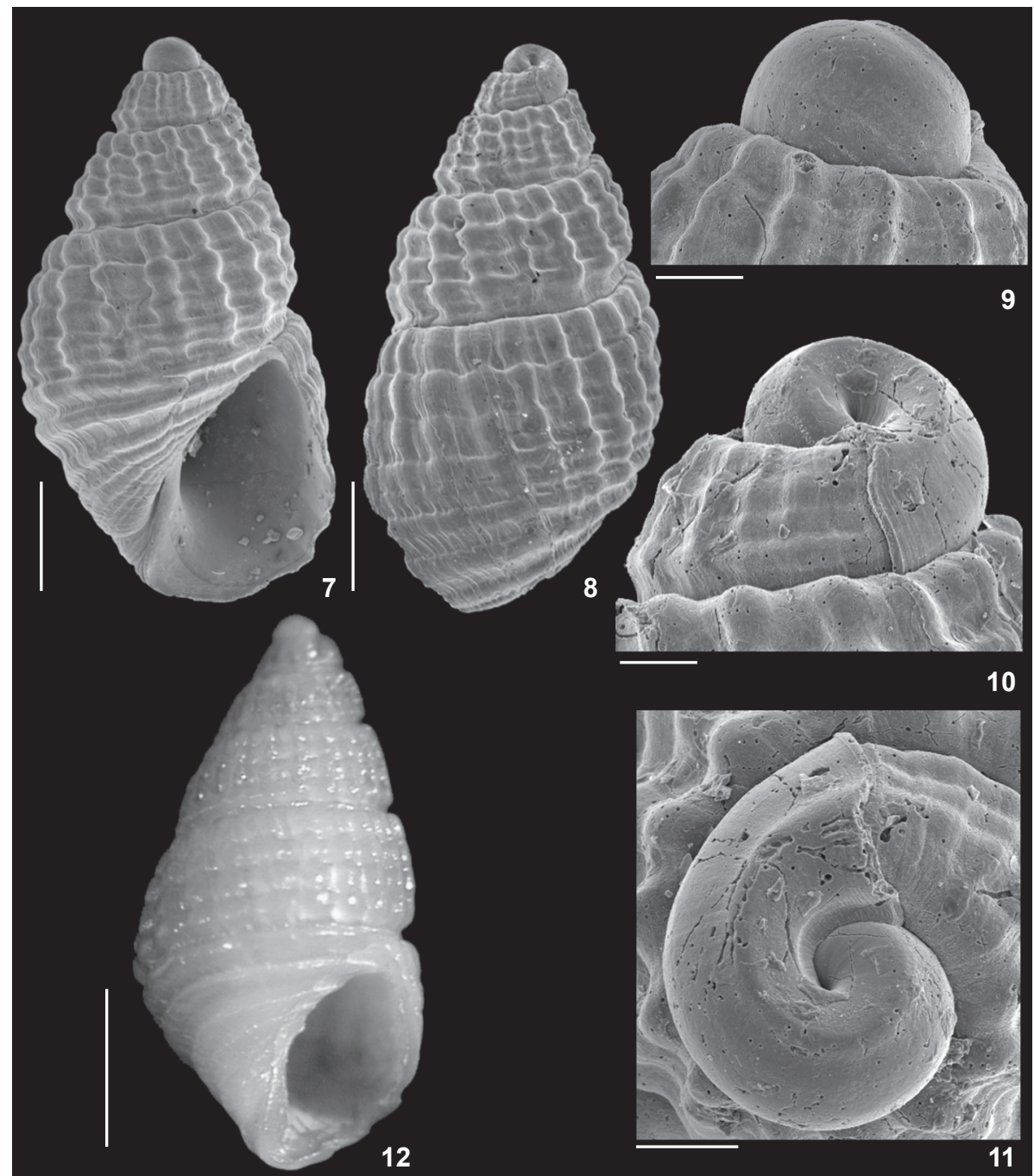

Figures 7-12. Chrysallida nioba: $(7-8,12)$ whole shells, respective lengths: $2.68,2.68,3.5$ mm; (9-11) protoconch. (7-11) IBUFRJ 11333; (12) syntype USNM 223284. Scale bars: $(7-8,12) 500 \mu \mathrm{m}$; (9-11) $100 \mu \mathrm{m}$.

pos, Rio de Janeiro state (HAB 16 sta B3, 22 $2^{\circ} 59^{\prime} 43^{\prime \prime} S$, $41^{\circ} 21^{\prime} 13^{\prime \prime} \mathrm{W}, 77 \mathrm{~m}$ ), 02/vii/2009; MZSP 99920 (REVIZEE Sul sta $6653,25^{\circ} 43.5^{\prime} \mathrm{S}, 46^{\circ} 2.5^{\prime} \mathrm{W}, 155 \mathrm{~m}$ ); MZSP 99921 (REVIZEE Sul sta $\left.6662,24^{\circ} 00.95^{\prime} \mathrm{S}, 43^{\circ} 55.54^{\prime} \mathrm{W}, 135 \mathrm{~m}\right)$; MZSP 99923 (REVIZEE Sul sta $6666,24^{\circ} 17.13^{\prime} \mathrm{S}, 4^{\circ} 12.15^{\prime} \mathrm{W}, 163 \mathrm{~m}$ ); MZSP 99924 (REVIZEE Sul sta 6666, $24^{\circ} 17.13^{\prime} \mathrm{S}, 4^{\circ} 12.15^{\prime} \mathrm{W}, 163 \mathrm{~m}$ ).

Type locality. Continental shelf of Campos Basin, Rio de Janeiro state, southeast of Brazil (HAB 16 sta C3, 22 $46^{\prime} 49^{\prime \prime} \mathrm{S}$, $41^{\circ} 3^{\prime} 16^{\prime \prime} \mathrm{W}, 78 \mathrm{~m}$ ).

Diagnosis. Small, conical shaped shell with pronounced spiral rows of nodules.

Description. Shell conical, color white. Teleoconch with up to four whorls, strictly straight in profile. Suture somewhat deep, straight. Protoconch heterostrophic, with $\sim 1$ smooth whorl, oriented in the opposite direction to the teleoconch axis, with no visible nucleus. Axial ribs markedly prosocline; 15 ribs on last whorl of holotype; interspaces about as wide as ribs, bearing microscopic axial growth lines. Spiral sculpture formed by three spiral cords per whorl, of same width as axial ribs, forming rounded nodules when crossing them, adapical row of nodules somewhat axially elongate; two adapical spiral cords somewhat closer to each other than the abapical cord, below which there is a moderately wide suprasutural spiral channel; additional fourth abapical spiral nodulose cord located on periphery of last whorl, smaller than other cords; base rhomboid with two low spiral cords and axial growth lines. Aperture rhomboid, tending to pyriform. Columella obliquely straight, with obsolete fold. Outer lip thin. No umbilical fissure. 


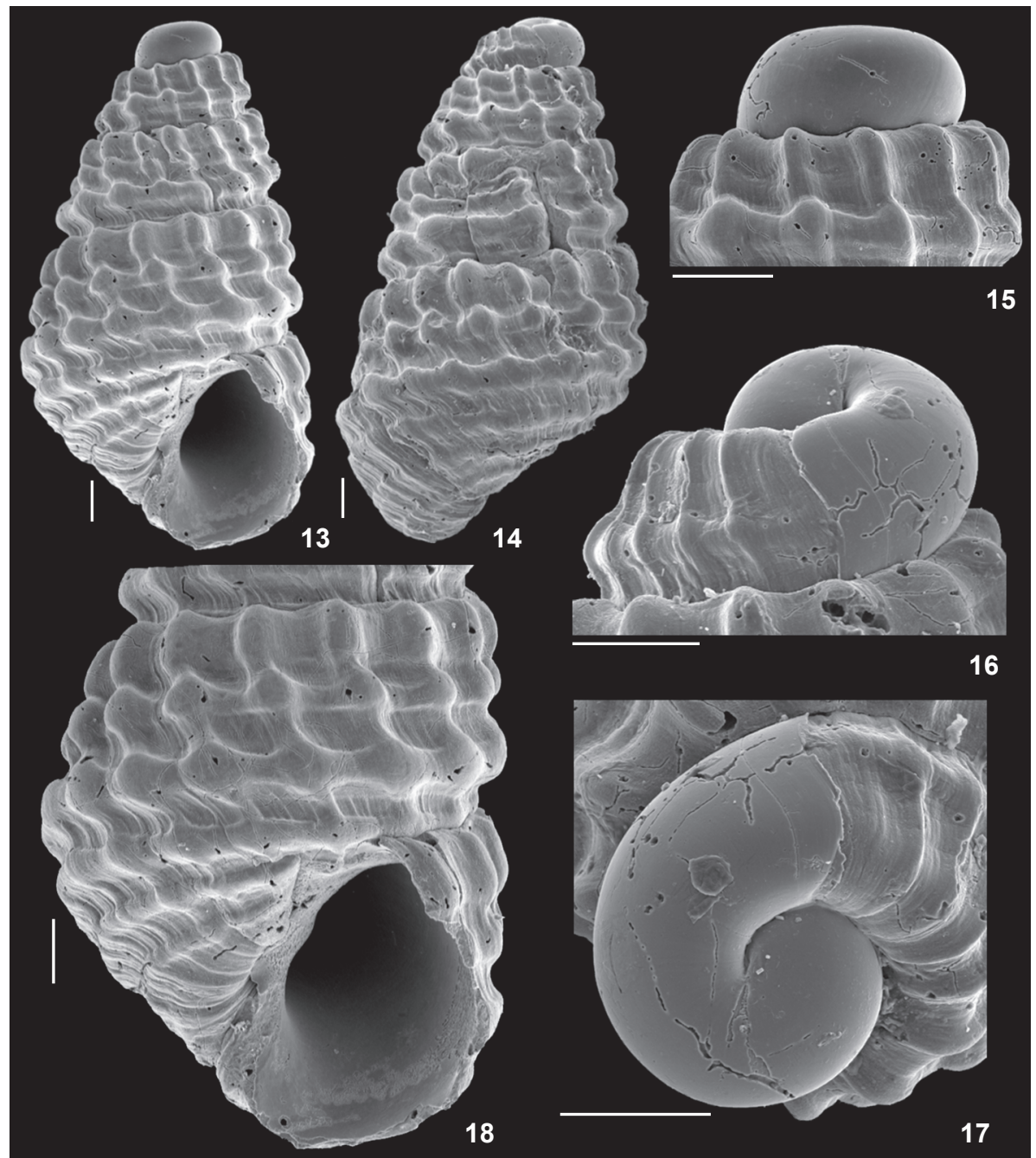

Figures 13-18. Chrysallida conifera, holotype: (13-14) whole shell, length: 1.35 mm; (15-17) protoconch; (18) last whorl. Scale bars: $100 \mu$ m.

Dimensions. Holotype with four teleoconch whorls; height $1.35 \mathrm{~mm}$; width $0.8 \mathrm{~mm}$; protoconch width: $260 \mu \mathrm{m}$.

Etymology. conifer, L. = cone bearing. This species is named after its strictly conical shell shape.

Geographic distribution. Continental shelves of Rio de Janeiro and São Paulo states, southeast of Brazil; $75 \mathrm{~m}$ to 163 $\mathrm{m}$ deep.

Remarks. Chrysallida conifera (Figs 13-17) somewhat resembles young specimens of Chrysallida gemmulosa, with a similar protoconch and general sculpture pattern, i.e., three nodulose spiral cords per whorl. However, the nodules of $C$. gemmulosa are axially arranged in a nearly orthocline direction, while in C. conifera they are prosocline (Figs 13-14 and 18); the whorl outline is slightly convex in C. gemmulosa and rectilinear in C. conifera (Figs 13-14). The main difference is at the base, which is elongate and ornamented with six or seven smooth spiral cords in C. gemmulosa, while in C. conifera there are three somewhat nodulose spiral cords (Fig. 18).

Chrysallida conifera is also somewhat similar to the illustration of Chrysallida cancellata (d'Orbigny, 1841) from the West Indies in DE Jong \& Coomans (1988: pl. 19, fig. 645). However, the original figure of the latter in D'Orbigny (1841: tab. XVII, figs 1-3), as well as examination of several specimens from the West Indies (ZMA collection; Aruba, West Indies, F. Veberne coll.), revealed shells with strongly convex whorl profiles and a rather ovoid last whorl, while $C$. conifera has a regularly flat whorl profile and a somewhat squarish last whorl (Figs 13-14 and 18). Chrysallida nioba Dall \& Bartsch, 1911 (Figs 7-11) is also similar to $C$. conifera, with very similar general shell sculpture. However, Chrysallida conifera has a more rectilinear outline of the whorls, truncate apex and squarish last whorl with a rhomboid base, while in C. nioba the spire is more acute and 
the last teleoconch whorl is more inflated and wide, with a somewhat elongate rounded base.

\section{Eulimastoma Bartsch, 1916}

Odostomia (Eulimastoma) Bartsch, 1916: 73. Type species by original designation: Odostomia (Scalenostoma) dotella Dall \& Bartsch, 1909.

\section{Eulimastoma exiguum sp. nov.}

Figs 19-24

Eulimastoma cf. weberi: Pimenta \& Absalão, 2004b: 168, fig. 5C-G.

Type material. Holotype: MNRJ 16308; paratypes: MNRJ 16309, type locality [2 shells]; MNHN IM-2012-6, MD55 sta CB96, east of Cabo de São Tomé, north coast of Rio de Janeiro state $\left(21^{\circ} 31^{\prime} \mathrm{S}, 40^{\circ} 08^{\prime} \mathrm{W}, 300 \mathrm{~m}\right), 31 / \mathrm{v} / 1987$ [7 shells]; MZSP 105121, MD55 sta CB96, east of Cabo de São Tomé, north coast of Rio de Janeiro state ( $\left.21^{\circ} 31^{\prime} \mathrm{S}, 40^{\circ} 08^{\prime} \mathrm{W}, 300 \mathrm{~m}\right), 31 / \mathrm{v} / 1987$ [4 shells]; IBUFRJ 12678 , REVIZEE Central sta C5-52C $\left(21.767^{\circ} \mathrm{S}\right.$, $\left.40,083^{\circ} \mathrm{W}, 450 \mathrm{~m}\right), 21 / \mathrm{vii} / 2001$ [9 shells].

Type locality. Continental shelf of Campos Basin, Rio de Janeiro state, southeast of Brazil; HAB 17 sta I3 (2123'33.709"S, $40^{\circ} 15^{\prime} 43.349^{\prime \prime}$ W, $88 \mathrm{~m}$ ).

Diagnosis. Small shell, without sculpture, with a spiral channel above suture and a marked spiral keel at periphery of base.

Description. Shell conical, color white. Teleoconch with up to 3.75 whorls almost straight in profile, slightly concave on last whorl; penultimate whorl with deep abapical channel, above suture, in a V-shaped outline; whorls gradually increase in width giving rise to a scaled shell shape. Suture deep, straight, covered by thin spiral callus. Protoconch heterostrophic with $\sim 1$ smooth whorls oriented in the opposite direction to the teleoconh axis, with no visible nucleus. Sculpture absent, except for growth lines and very thin spiral incisions irregularly spaced, almost inconspicuous. Base rounded, market at adapical periphery by a well marked spiral keel. Aperture obliquely ovoid. Columella obliquely arcuate, without fold. Outer lip thin. Umbilicus as a very narrow fissure.

Dimensions. Holotype with 3.75 teleoconch whorls; height $1.3 \mathrm{~mm}$; width $0.6 \mathrm{~mm}$; protoconch width: $432 \mathrm{~mm}$.

Geographic distribution. Continental shelf and slope of north coast of Rio de Janeiro state, southeast of Brazil; $88 \mathrm{~m}$ to $450 \mathrm{~m}$ deep.

Etymology. exiguus, L. = poor, scanty. This species is named after its lack of shell sculpture.

Remarks. Shells of Eulimastoma exiguum were illustrated by Pimenta \& ABSALÃo (2004b) but named Eulimastoma aff. weberi (Morrison, 1965). In that paper, the authors were not confident in recognizing a different taxon, because of the little material available. Examination of material collected from the MD55 and Habitats expeditions allowed the conclusion that this is a new species, distinct from E. weberi.
Both species have small shells with a scaled telecoconch whorl and somewhat similar channeled suture, but E. weberi has distinct spiral cords above and below the suture, while in E. exiguum, this sculpture is absent (Figs 19-20 and 24).

\section{Eulimastoma franklini sp. nov.}

Figs $25-30$

Eulimastoma aff. didyma: Pimenta \& Absalão, 2004b: 166, fig. $4 \mathrm{~J}-\mathrm{K}$.

Type material. Holotype: MNRJ 17168; paratypes: UERJ 3330 , type locality [3 shells]; MNRJ 17167, type locality [2 shells]; MNHN IM-2012-7, type locality [1 shell]; UERJ 3339, RAP Ilha Grande sta $15\left(23^{\circ} 3.762^{\prime} \mathrm{S}, 4^{\circ} 36.038^{\prime} \mathrm{W}, 7 \mathrm{~m}\right)$, Ponta Grande, Timuíba, Paraty, 19/xi/2003, [5 shells]; MNRJ 17169, Enseada de Dois Rios, Ilha Grande, 19-20/xi/1996 [4 shells].

Type locality. Ponta Grande, Ilha Grande Bay, South coast of Rio de Janeiro state, southeast of Brazil; Ilha Grande RAP

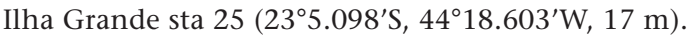

Diagnosis. Protoconch helicoidal with $\sim 2.25$ whorls; base with two spiral ridges at adapical periphery.

Description. Shell small, conical, color white. Teleoconch with up to four whorls rectilinear in profile. Suture deep, straight. Protoconch heterostrophic helicoidal, with $\sim 2.25$ smooth whorls oriented $\sim 80^{\circ}$ to teleococnh axis. Sculpture absent, except for one spiral ridge at abapical region of each whorl, above suture. Base straight, market at adapical periphery by three spiral ridges. Aperture rhomboid tending to pyriform. Columella obliquely arcuate, with a distinct fold. Outer lip thin. Umbilicus as a very narrow fissure.

Dimensions. Holotype with four teleoconch whorls; height $1.4 \mathrm{~mm}$; width $0.8 \mathrm{~mm}$; protoconch width: $210 \mathrm{~mm}$.

Geographic distribution. Known only for shallow waters (7 $\mathrm{m}$ to $17 \mathrm{~m}$ deep) at Ilha Grande bay, south coast of Rio de Janeiro state, southeast of Brazil.

Etymology. This species is named after in honor of Dr. Franklin Noel dos Santos, Brazilian malacologist, who took part at RAP Ilha Grande project, in the malacological team.

Remarks. Shells of Eulimastoma franklini were illustrated by Pimenta \& ABSALÃo (2004b) but termed Eulimastoma aff. didymum. The authors recognized a single difference from $E$. didymum in the protoconch shape, but because of the little material available, decided not to describe it.

Examination of new material, also collected at Ilha Grande, allowed the recognition of a new species. Eulimastoma franklini (Figs 25-30) is indeed very similar to E. didymum in shell shape and teleoconch sculpture. Both species have regular conical shells, with a straight whorl outline and a wide spiral cord above the suture.

The main difference that clearly distinguishes the two species is the type of protoconch, concerning its orientation to the teleoconch axis. Although it is not visible in the eroded holotype, E. didymum has an upturned protoconch according 


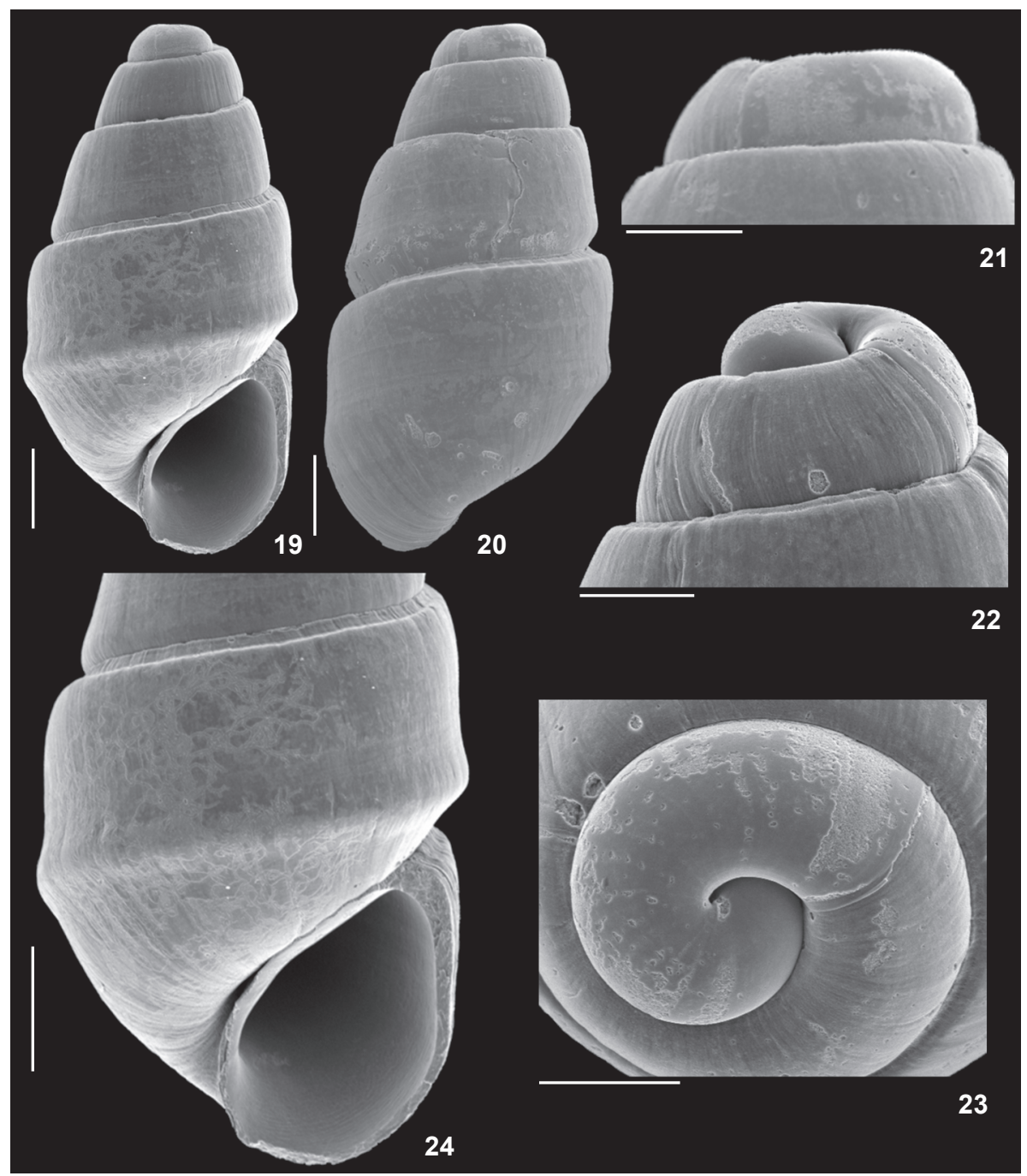

Figures 19-24. Eulimastoma exiguum. (19-20) whole shell, lengths: 1.3mm; (21-23) protoconch; (24) last whorl. (19, 22, 24) holotype; (20-21, 29) paratype MNRJ 16309. Scale bars: $(10-20,24) 200 \mu \mathrm{m} ;(21-23) 100 \mu \mathrm{m}$.

to its original description (Verrill \& Bush, 1900) and as also illustrated by WiSe (1996) in specimens from Texas and by Pimenta \& AbSALÃo (2004b) in specimens from southeast Brazil. In E. franklini, the protoconch is oriented about $80^{\circ}$ to the teleoconch axis (Figs 27-29).

Pimenta \& ABSAlÃo (2004b) described intraspecific variation in E. dydima regarding the expression of the subsutural spiral cord, and the presence of spiral striae at the base, from smooth bases to those covered by several grooves. In E. franklini, on the other hand, all shells studied have smooth bases (Fig. 30) and lack the subsutural spiral cord on the teleoconch whorls (Figs 25-26 and 30).

In Brazil, E. franklini and E. didymum occur at the same localities, on the southeast coast. Both species were collected in
Ilha Grande Bay, but while E. franklini is only known from Ilha Grande Bay, E. didymum was found in localities on the northeast and north coast of Brazil, up to $\sim 3^{\circ} \mathrm{N}$ (Pimenta \& ABSAlão 2004b).

\section{Parthenina}

\section{Bucquoy, Dautzenberg \& Dollfus, 1883}

Parthenina Bucquoy, Dautzenberg \& Dollfus, 1883. Type species by monotypy: Turbo interstinctus Montagu.

\section{Parthenina biumbilicata sp. nov.}

Figs 31-36

Type material. Holotype: MORG 50990, REVIZEE Central sta D3; paratypes: MNRJ 16306, HAB 16 sta H4 (2142'49"S, 


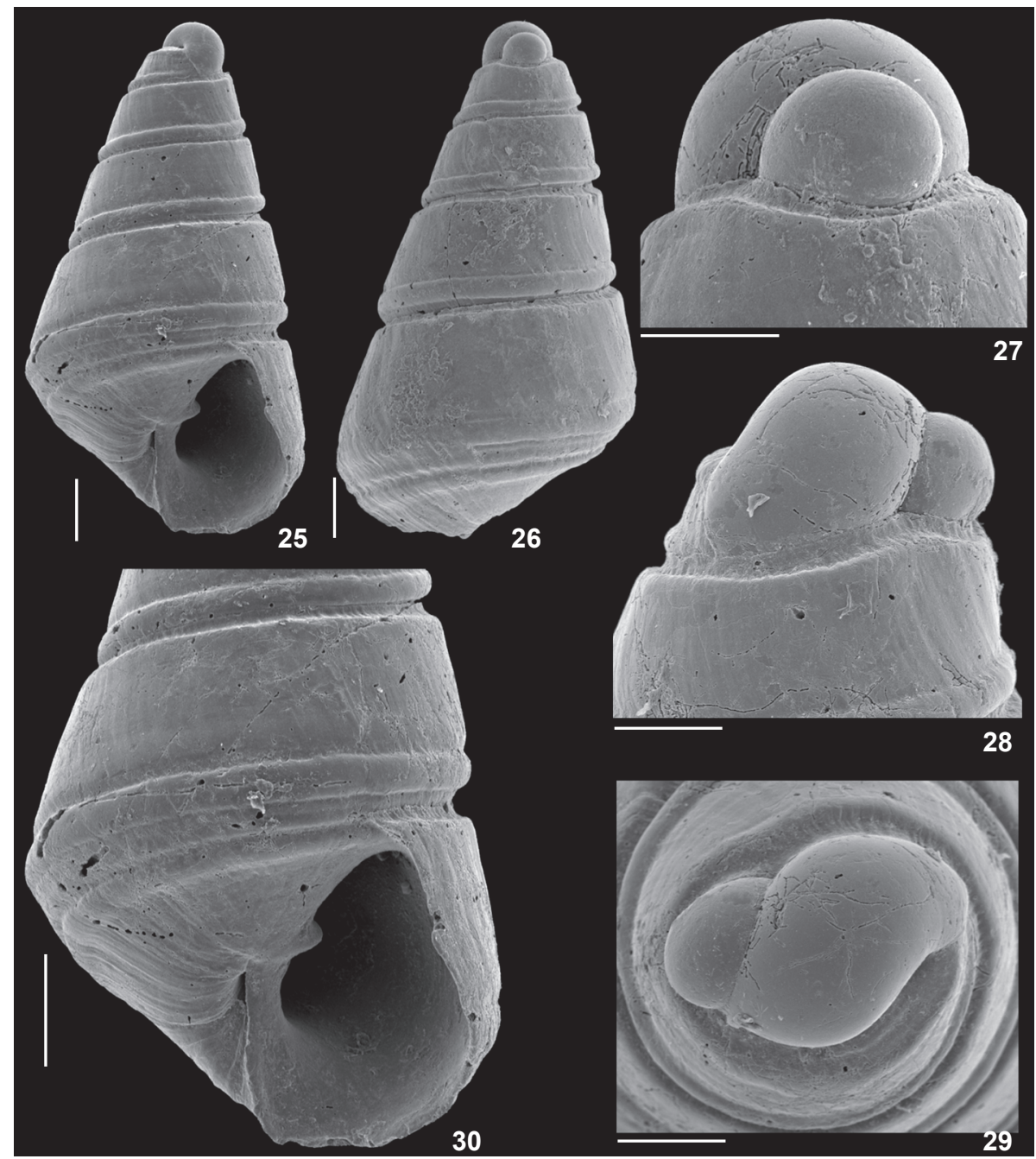

Figures 25-30. Eulimastoma franklini. (25-26) whole shell, lengths: $1.4 \mathrm{~mm}$; (27-29) protoconch; (30) last whorl. (25-30) holotype. Scale bars: $(25-26,30) 200 \mu \mathrm{m}$; (27-29) $100 \mu \mathrm{m}$.

$\left.40^{\circ} 10^{\prime} 21^{\prime \prime} \mathrm{W}, 97 \mathrm{~m}\right)$, [1 shell]; MNRJ 16307, HAB 16 sta F3

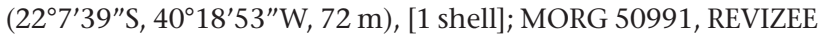
Central sta C1-D1 $\left(22^{\circ} 48^{\prime} \mathrm{S}, 41^{\circ} 091^{\prime} \mathrm{W}, 69 \mathrm{~m}\right), 23 / 02 / 96$ [1 shell]; UERJ 3334, RAP Ilha Grande sta 3, [1 shell]; UERJ 3348, RAP Ilha Grande sta 15, [2 shells]; UERJ 3332, RAP Ilha Grande sta 25 ( $23^{\circ} 5.098^{\prime} \mathrm{S}, 44^{\circ} 18.603^{\prime} \mathrm{W}, 17 \mathrm{~m}$ ), Ilha Queimada Grande, 31/x/ 2003, [1 shell]; UERJ 6192, RAP Ilha Grande sta 9 (23⒐101'S,

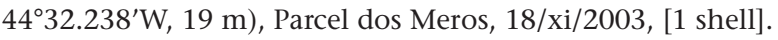

Type locality. Continental shelf of north of Rio de Janeiro state, southeast of Brazil REVIZEE Central sta C1-D3 (22 ${ }^{\circ} 52^{\prime}$ 'S, $\left.41^{\circ} 09^{\prime} \mathrm{W}, 80 \mathrm{~m}\right)$.

Diagnosis. Shell with deep, wide umbilicus; teleoconch sculpture of very thin and close together sinoidal axial ribs; protoconch with regularly increasing aperture diameter and with small circular umbilicus.
Description. Shell conical, color white. Teleoconch with up to four whorls slightly convex in profile. Suture somewhat deep and slightly sinoidal, crenulated by projection of axial ribs summits. Protoconch heterostrophic with $\sim 1.5$ smooth whorls oriented in the opposite direction to the teleoconch axis, with no visible nucleus and small circular umbilicus. Axial ribs prosocline, slightly sinoidal, very closed each other, living very narrow interspaces; 40 ribs on last whorl of holotype. Spiral sculpture formed by four to five strong spiral cords, of same width as axial ribs, located at $\sim 2 / 3$ abapical region of each whorl, forming small nodules when crossing axial ribs; adapical $\sim 1 / 3$ of whorl with very evanescent spiral cords; additional abapical spiral nodulose cord located on periphery of last whorl; base somewhat rounded with three low spiral cords and axial growth lines. Aperture ovoid. Columella obliquely curved, with- 


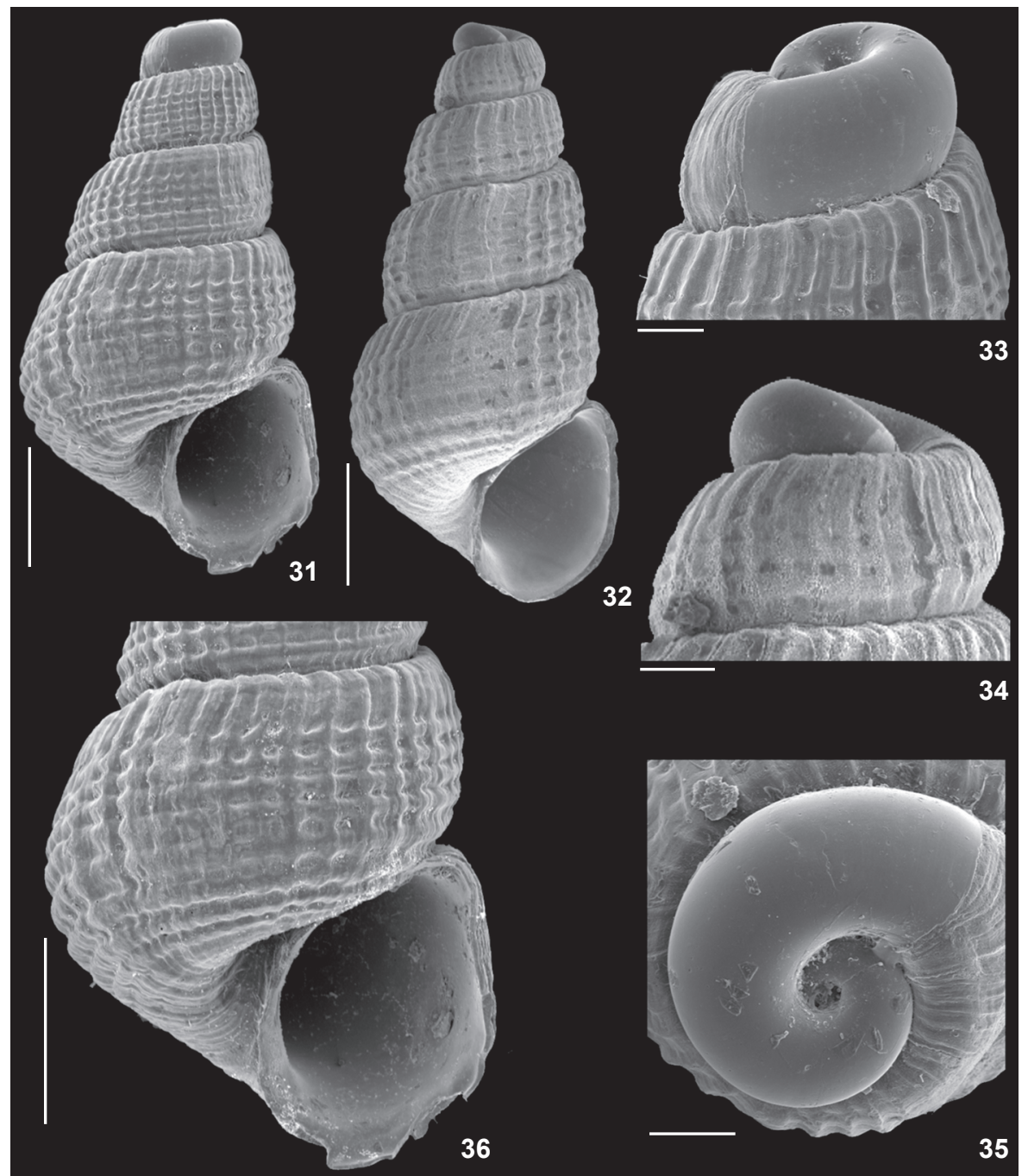

Figures 31-36. Parthenina biumbilicata. (31-32) whole shell, respective lengths: (31) $2.35 \mathrm{~mm},(32) 2.41 \mathrm{~mm}$; (33-35) protoconch; (36) last whorl. $(31,33,35-36)$ holotype; $(32,34)$ paratype MORG 50991. Scale bars: $(31-32,36) 500 \mathrm{~mm} ;(33-35) 100 \mu \mathrm{m}$.

out fold. Outer lip thin. Umbilicus wide, deep and circular. Dimensions. Holotype with 3.5 teleoconch whorls; height $2.35 \mathrm{~mm}$; width $1.2 \mathrm{~mm}$; protoconch width: $370 \mathrm{~mm}$.

Geographic distribution. Continental shelf of Rio de Janeiro state, southeast of Brazil; $17 \mathrm{~m}$ to $97 \mathrm{~m}$ deep.

Etymology. This species is named after its conspicuous umbilicus at both last teleoconch whorl and at protoconch.

Remarks. Parthenina was used by AARTSEN et al. (2000) as a subgenus of Chrysallida to include species with small shells ornamented with sinuous axial ribs crossed by weaker spiral cords, restricted to the lower (abapical) region of the teleoconch whorl. Many species with this same sculpture pattern were considered by Linden \& EIKenboom (1992) and by Peñas \& Rolán (1998) as Chrysallida lato sensu. Schander et al. (2003) consid- ered Parthenina at the full genus rank, after including three species from the eastern Atlantic in a molecular phylogenetic analysis.

Pimenta et al. (2009) followed Schander et al. (2003) in considering Parthenina at the genus rank, and listed two taxa from Brazil: Parthenina varia (Odé, 1993) and Parthenina cf. interspatiosa (Linden \& Eikenboom, 1992). This latter taxon was considered by Pimenta et al. (2009) to have a somewhat dubious taxonomic status, due to its identical shell morphology to specimens from the eastern Atlantic and the lack of biological data to consider them co-specific.

Parthenina biumbilicata has a teleoconch sculpture of sinuous axial ribs and weak spiral cords (Figs 31-36), but the spiral cords are also present on the adapical $\sim 2 / 3$ of the teleoconch 
whorl, though as very tiny cords. The most similar taxon from the western Atlantic is that recorded by PIMENTA et al. (2009) as $P$. cf. interspatiosa, but $P$. biumbilicata has more numerous axial ribs which are closer together. The number of spiral cords is also higher in $P$. biumbilicata, four to five, while in $P$. cf. interspatiosa there are only one or two.

Compared to the European Parthenina species described by AARTSEn et al. (2000) and those included in Chrysallida sensu lato by Linden \& Eíemboom (1992) and Peñas \& Rolán (1998), $P$. biumbilicata has some similarity with C. juliae (de Folin, 1872), mainly due to the axial ribs close together, but $P$. biumbilicata is wider and more conical and the axial ribs do not continue over the base (Fig. 36) as in the redescription of C. juliae by Linden \& Eikenbomm (1992). In addition, the umbilicus of $P$. biumbilicata is wider and deeper (Fig. 36).

REDFERN (2001) illustrated a very similar shell from Abaco, Bahamas, named Chrysallida sp. It has the same conical shell shape, teleoconch sculpture and pronounced umbilicus.

\section{ACKNOWLEDGEMENTS}

We are grateful to P. Bouchet and P. Maestrati (MNHN), L. Simone (MZSP), Robert Moolenbeeck (ZMA), E. Rios and P.S. Oliveira (MORG), R. Absalão (IBUFRJ), S.B. Santos (UERJ), C. Miyaji, for loan of material. E. Rolán, C. Redfern, and F.N. Santos, for exchanging information about Pyramidellidae taxonomy. The two referees, for their critics and suggestions. A. Veiga, for SEM operation at the Departamento de Invertebrados (MNRJ). J. Reid, for revising the English text. Petrobras, for making the collection and study of material from the Habitats Project possible. CENPES/Petrobras, for the establishment of the Center for Scanning Electron Microscopy of Museu Nacional/UFRJ through Project 'Modernização, informatização e infra-estrutura das coleções marinhas do Museu Nacional/UFRJ e desenvolvimento do Centro de Microscopia Eletrônica de Varredura' (SAPE 460022548-3).

\section{LITERATURE CITED}

Aartsen, J.J. van. 1981. European Pyramidellidae: II. Turbonilla. Bollettino Malacologico 17 (5-6): 61-68.

Aartsen, J.J. van. 1987. European Pyramidellidae: III. Odostomia and Ondina. Bollettino Malacologico 23 (1-4): 1-34.

Aartsen, J.J. van; E. Gittenberger \& J. Goud. 2000. Pyramidellidae (Mollusca, Gastropoda, Heterobranchia) collected during the Dutch CANCAP and MAURITANIA expeditions in the southeastern part of the North Atlantic Ocean (part 2). Zoologische Mededelingen 74: 1-50.

Аввотт, R.T. 1974. American Seashells. New York, Van Nostrand Reinhold Co., $2^{\text {nd }}$ ed., 663p.

Absalão, R.S.; F.N. Santos \& D. de O. Tenório. 2003. Five new species of Turbonilla Risso, 1826 (Gastropoda, Heterobranchia, Pyramidellidae) found off the northeast coast of Brazil $\left(02^{\circ}-13^{\circ}\right.$
S). Zootaxa 235: 1-11.

Adams, A. 1861. On a new genus and some new species of Pyramidellidae from the north of China. Annals and Magazine of Natural History (3) 7: 295-299.

ADAms, A. 1863. On the species of Pyramidellidae found in Japan. Journal of the Proceedings of the Linnean Society of London 7: 1-6.

ADAms, C.B. 1839. Observations on some species of the marine shells of Massachusetts, with descriptions of five new species. Boston Journal of Natural History 2: 262-288.

Adams, C.B. 1852. Catalogue of shells collected at Panama with notes on synonymy, station and habitat. Annals Lyceum Natural History 5: 222-549.

Bartsch, P. 1909. Pyramidellidae of New England and the adjacent region. Proceedings of the Boston Society of Natural History 34 (4): 67-113.

BARTSCH, P. 1916. Eulimastoma, a new subgenus of pyramidellids, and remarks on the genus Scalenostoma. The Nautilus 30 (7): 73-74.

BARTSCH, P. 1955. The pyramidellid mollusks of the Pliocene deposits of North St. Petersburg, Florida. Smithsonisn Miscellaneous Collections 125 (2): 1-102.

Boettger, O. 1901. Zur Kenntnis der Fauna der mittelmiozänen Schichten von Kostej im Krassó-Szörényer Komitat. Verhandlugen und Mitteilungen des siebenbürgischen Vereins für Naturwisschenschaften Hermannstadt 51: 1-200.

Bucquoy, E.P.; P. Dautzenberg \& G. Dollfus. 1883. Les mollusques marins du Roussillon. Paris, vol. 1, 195p.

CARPENTER, P.P. 1856. Description of new species and varieties of Calyptraeidae, Trochidae, and Pyramidellidae, principally in the collections of Hugh Cuming, Esq. Proceedings of the Zoological Society of London 24: 166-171.

DALL, W.H. \& P. BARTSCH. 1903. Contributions to the Tertiary fauna of Florida with special reference to the Miocene silexbeds of Tampa and the Pliocene beds of the Caloosahatchie River. Part 6. Concluding the work. Transactions of the Wagner Free Institute of Science 3 (6): 1219-1654.

DALL, W.H. \& P. BARTSCH. 1904. Synopsis of the genera, subgenera and sections of the family Pyramidellidae. Proceedings of the Biological Society of Washington 17: 1-16.

Dall, W.H. \& P. BARTSCH, P. 1909. A monograph of West American Pyramidellid mollusks. Bulletin of the United States National Museum 68, xii +258 pp.

Dall, W.H. \& P. BARTSCH, 1911. New species of shells from Bermuda. Proceedings of the United States National Museum 40 (1820): 277-288.

Folin, L. DE. 1872-1876. Les fonds de la mer. Paris, F. Savy, vol. $1,365 p$.

Gray, J.E. 1840. Synopsis of the contents of the British Museum. London, $42^{\text {th }}$ ed., 370p.

Henderson, J.B. \& P. Bartsch. 1914. Littoral marine mollusks of Chincoteague Island, Virginia. Proceedings of The United States National Museum 47 (2055): 411-421. 
JonG, K.M. DE \& H.E. Coomans. 1988. Marine Gastropods from Curacao, Aruba and Bonaire. Leiden, E.J. Brill, 261p.

Lee, H.G. 2009. Marine Shells of Northeast Florida. Florida, Jacksonville Shell Club, 204p.

LINDEN, J. VAN DER \& J.C.A. EIKENBOOM. 1992. On the taxonomy of the Recent species of the genus Chrysallida Carpenter from Europe, the Canary Islands and the Azores (Gastropoda, Pyramidellidae). Basteria 56: 3-63.

Lygre, F.; J.A. Kongsrud \& C. Schander. 2011. Four new species of Turbonilla (Gastropoda, Pyramidellimorpha, Turbonillidae) from the Gulf of Guinea, West Africa. African Invertebrates 52 (2): 243-254.

Lyons, W.C. 1989. Nearshore marine ecology at Hutchinson Islands, Florida: 1971-1974. XI. Mollusks. Florida Marine Research Publications 47: 1-131.

Monterosato, T.A. Di. 1884. Nomenclatura generic e specifica di alcune conchiglie Mediterranee. Palermo, 152p.

Morrison, J.P.E. 1965. New Brackish water mollusks from Lousiana. Proceedings of the Biological Society of Washington 78: 217-224.

ODÉ, H. 1993. Distribution and records of the marine Mollusca in the northwest Gulf of Mexico (a continuing monograph). Texas Conchologist 30 (1): 23-32.

ODÉ, H. \& A.B. SPEERs. 1972. Notes concerning Texas beach shells. Texas Conchologist 9 (1): 1-17.

D'Orbigny, A. 1835-1846. Voyage dans L'Amerique Méridionale. Mollusques. Paris, 1-48 (1835); 49-184 (1836); 185-376 (1837); 377-408 (1840); 409-488 (1841); 489-758 (1846).

PelseneER, P. 1928. Les parasites des mollusques el les mollusques parasites. Bulletin de la Societé Zoologique de France 53: 158-189.

Peñas, A. \& E. Rolán. 1998. Pyramidellidae (Gastropoda, Heterostropha) de la Missión Oceanográfica "Seamount 2". Iberus, Suplemento 5: 151-199.

Pimenta, A.D. \& R.S. Absalão. 2001a. Taxonomic revision of the species of Turbonilla Risso, 1826 (Gastropoda, Heterobranchia, Pyramidellidae) with type localities in Brazil, and description of a new species. Basteria 65: 69-88.

Pimenta, A.D. \& R.S. AbsalÃo. 2001b. The genera Bacteridium Thiele, 1929 and Careliopsis Mörch, 1875 (Gastropoda: Pyramidellidae) from the east coast of South America. Bollettino Malacologico 37: 41-48.

Pimenta, A.D. \& R.S. AbSALÃo. 2002. On the taxonomy of Turbonilla puncta (C.B. Adams, 1850) (Gastropoda, Pyramidellidae), with the description of a new species from Brazil and remarks on other western Atlantic species. Zootaxa 78: 1-16.

Pimenta, A.D. \& R.S. Absalão. 2004a. Fifteen new species and ten new records of Turbonilla Risso, 1826 (Gastropoda, Heterobranchia, Pyramidellidae) from Brazil. Bollettino Malacologico 39: 113-140.

Pimenta, A.D. \& R.S. Absalão. 2004b. Review of the genera Eulimastoma Bartsch, 1916 and Egila Dall and Bartsch, 1904 (Mollusca, Gastropoda, Pyramidellidae) from Brazil. Zoosys- tema 26: 157-173.

Pimenta, A.D.; R.S. Absalão. \& A.S. Alencar. 2000. Odostomella carceralis spec. nov. from Ilha Grande, SE Brazil (Gastropoda: Heterobranchia, Pyramidellidae). Basteria 64: 65-70.

Pimenta, A.D.; F.N. Santos \& R.S. Absalão. 2008. Review of the genera Ividia, Folinella, Menestho, Pseudoscilla, Tryptichus and Peristichia (Gastropoda, Pyramidellidae) from Brazil, with descriptions of four new species. The Veliger 50: 171-184.

Pimenta, A.D.; R.S. Absalão \& C. Miyaji. 2009. A taxonomic review of the genera Boonea, Chrysallida, Parthenina, Ivara, Fargoa, Mumiola, Odostomella and Trabecula (Gastropoda, Pyramidellidae, Odostomiinae) from Brazil. Zootaxa 2049: 39-66.

Pimenta, A.D.; F.N. Santos \& R.S. AbSALÃo. 2011 Taxonomic revision of the genus Eulimella (Gastropoda, Pyramidellidae) from Brazil, with description of three new species. Zootaxa 3063: 22-38.

REDFERn, C. 2001. Bahamian Seashell. Boca Raton, Bahaminaseashells.com, Inc. 280p.

Rios, E.C. 1994. Seashells of Brazil. Rio Grande, Museu Oceanográfico Prof. E.C. Rios, Fundação Universidade de Rio Grande, $2^{\text {nd }}$ ed, 368p.

Rios, E.C. 2009. Compendium of Brazilian Seashells. Rio Grande, Editora Evangraf, 668p.

RoBERTSON, R. 1978. Spermatophores of six eastern north American Pyramidellid Gastropods and their systematic significance (with the new genus Boonea). Biological Bulletin of the Marine Biological Laboratory 155: 360-382.

Robertson, R. 1996. Fargoa bartschi (Winkley, 1909): a littleknown Atlantic and Gulf coast American odostomian (Pyramidellidae) and its generic relationships. American Malacological Bulletin 13: 11-21.

Rosenberg, G. 2009. Malacolog v. 4.1.1: A Database of Western Atlantic Marine Mollusca. Available online at: www.malacolog.org [Accessed: 2012].

Schander, C. 1994. Twenty-eight new species of Pyramidellidae (Gastropoda, Heterobranchia) from West Africa. Notiziario Centro Italiano Studi Malacologici 15: 11-78.

Schander, C.; J.J. van Aartsen \& J. Corgan. 1999. Families and genera of the Pyramidelloidea (Mollusca: Gastropoda). Bollettino Malacologico 34 (9-12): 145-166.

Schander, C.; K.M. Halanych; T. Dahlgren \& P. Sunberg. 2003. Test of the monophyly of Odostomiinae and Turbonilliinae (Gastropoda, Heterobranchia, Pyramidellidae) based on $16 \mathrm{~S}$ mtDNA sequences. Zoologica Scripta 32 (3): 243-254.

Tavares, M. 1999. The cruise of the Marion Dufresne off the Brazilian coast: account of the scientific results and list of stations. Zoosystema 21 (4): 597-605.

Tunnell Jr, J.W.; J. Andrews; N.C. Barrera \& F. Moretzsohn. 2010. Encyclopedia of Texas Seashells - Identification, Ecology, Distribution \& History. City of Corpus Christi. Harte Research Institute for Gulf of Mexico Studies Series, XI+512p.

Verrill, A.E. \& K. J. Bush. 1900. Additions to the marine mollusca of the Bermuda. Transactions of the Connecticut Academy of Sciences 10: 513-544. 
Wells, H. \& M.J. Wells. 1961. Three species of Odostomia from North Carolina, with description of a new species. The Nautilus 74: 149-157.
Wise, J.B. 1996. Morphology and phylogenetic relationships of certain pyramidellid taxa (Heterobranchia). Malacologia 37: 443-551.

Submitted: 06.III.2012; Accepted: 20.VI.2012.

Editorial responsibility: Marcos D.S. Tavares 